\title{
TEACHERS' STRATEGIES IN TEACHING SPOKEN LANGUAGE TO YOUNG LEARNERS AT CITA HARMONI MONTESSORI SCHOOL
}

\author{
Intan Febyawati ${ }^{\left.a^{*}\right)}$, Lungguh Halira Vonti ${ }^{\text {a) }}$, Entis Sutisna ${ }^{\text {a) }}$ \\ a) Universitas Pakuan, Kota Bogor, Indonesia \\ ${ }^{*}$ e-mail korespondensi: intanfebyawati@gmail.com
}

\section{Riwayat Artikel}

diterima 02 Juni 2021

direvisi 18 Juni 2021

disetujui 28 Juli 2021

\begin{abstract}
.
Learning foreign language becomes one of the needs that should be trained from an early start. Children from an early age have to be prepared to be ready for it as they will learn to communicate with others. Therefore, in order to assist the children in learning to talk the new language, young learners' teachers need to create such activities that can improve the students' ability to speak. However, in the application, the teachers are often questioning what strategies to prepare in order to teach spoken language to young learners. This research aims to investigate the strategies applied by the teachers in teaching spoken language to young learners. Four teachers are involved as participants in this research. This qualitative research uses descriptive analysis design to describe the strategies applied by the teachers at Cita Harmoni Montessori School in teaching spoken language to young learners. Three steps of triangulation are used in this research, they are; classroom observation, interview, and focus group discussion. The findings show that the teachers employ some strategies in order to teach spoken language to young learners who are around four until six years of age. Those strategies are; conversation, talking partner, repetition, gesture, picture, flashcard, song, and video.
\end{abstract}

Keywords: Teaching Strategy, Spoken Language, Young Learners

\section{STRATEGI GURU DALAM MENGAJAR BAHASA LISAN KEPADA ANAK - ANAK DI SEKOLAH CITA HARMONI MONTESSORI}

\begin{abstract}
Abstrak. Mempelajari Bahasa asing menjadi salah satu kebutuhan yang harus dilatih sejak dini. Anak-anak mulai usia dini sudah seharusnya dipersiapkan akan hal itu sejalan dengan mereka yang lambat laun akan belajar berkomunikasi dengan orang lain. Oleh karena itu, dalam rangka membantu anak mempelajari Bahasa yang terbilang baru bagi mereka, para guru sebaiknya merancang aktivitas pembelajaran yang dapat meningkatkan kemampuan anak untuk berbahasa. Namun, pada pengaplikasiannya, masih terdapat guru-guru yang mempertanyakan strategiapa saja yang seharusnya disiapkan oleh mereka untuk mengajarkan Bahasa lisan dalam Bahasa inggris kepada anak-anak. Penelitian ini ditujukan untuk mencari tahu strategi apa saja yang diaplikasikan oleh para guru dalam mengajarkan Bahasa lisan kepada anak-anak. Sebanyak empat guru dari taman kanak-kanak diikutsertakan sebagai partisipan dalam penelitian ini. Penelitian kualitatif ini menggunakan teknik analisis deskriptif untuk mendeskripsikan strategi-strategi yang diaplikasikan oleh keempat guru di Sekolah Montessori Cita Harmoni dalam mengajarkan Bahasa lisan kepada anak-anak. Tiga tahap triangulasi yang digunakan dalam penelitian ini, diantaranya; observasi kelas, wawancara, dan diskusi grup yang terfokus. Hasil penelitian menunjukkan bahwa para guru tersebut mengaplikasikan beberapa strategi untuk mengajarkan Bahasa lisan kepada anak- anak usia empat sampai enam tahun. Strategi-strategi yang tersebut adalah; percakapan, berbicara dengan rekan, pengulangan, Bahasa tubuh, gambar, kartu, lagu, dan video.
\end{abstract}

Kata Kunci: Strategi Mengajar, Bahasa Lisan, Anak-anak

\section{INTRODUCTION}

Learning foreign language from an early start benefits the learners to acquire the language easily. Learners who have been introduced to English language since early childhood learn better than adults or adolescents. It is claimed that at this age, children come into an optimal period in which the brain assisted language acquisition called Critical Period Hypothesis (CPH). Thus, the preeminent time for children to learn foreign languages can be started very soon by considering the aspects that may affect the learning.

Based on the idea stated by the philosophy of education, Maria Tecla Artemisia Montessori, a child learns better when the classroom is designed as a prepared environment and the concrete materials are brought as a media for learning. Hence, choosing a suitable approach and addressing the needs of each child should be considered. A classroom should be well-set in order to offer massive opportunities to children to choose what to learn based on their interests. When the needs of one period are fully served, the future of children will lead to a successful learning.

The curriculum offered by Maria Montessori is designed as a child-centered program that focuses on four working areas: practical life area, sensorial area mathematical area, and language area.

In language learning area, Montessori provides opportunities for children to learn four areas for instance: spoken language, vocabulary enrichment, written language, and art of reading. Spoken language stands in the first stage of language learning since it is found that a child seems to pay more attention to what they hear as sound and prosody. 
Therefore, practicing spoken language is necessary since it can improve fluency and offer huge opportunities for the children to talk more active.

For that reasons, the teachers of young learners need to involve the students in the practicing the spoken language to ensure that the students use the target language in order to improve the children to talk more and fluently; also, to develop communicative skill and knowledge of each student.

As suggested by Imaniah and Nargis (2017:63-64), that young learners' teachers need to bring such activities that can involve the students to practice spoken language actively in the class throughout conversation, partner work, talking partner, and role play. Moreover, they suggest young learners' teacher to use L1 or Bahasa Indonesia as the alternative resource to assist the students in learning the target language.

According to Eggins (2004: 92-93) characteristics of spoken language are broken down into five; interactive, face to face, spontaneous, casual, and language as an action.

The term interactive means that the activity needs at least two or more participant. Moreover, the term face to face infers that the activity has to be done in the same time and at the same place. The spoken language is a kind of spontaneous that means it is produced without rehearsing what is going to be said. It uses casual language that implies the language used in teaching spoken language should be informal or the language that used in daily. Besides, it also functions as an action which implies that spoken language is also used to accomplish some tasks.

\section{RESEARCH METHODOLOGY}

In this research, the researcher chooses a qualitative approach since it is intended to investigate the strategies implemented in teaching spoken language to young learners. Moreover, descriptive analysis design is used to describe the strategies implemented in teaching spoken language by teachers at Montessori School. Three steps of triangulation are arranged in order to collect the data; (1) classroom observation, (2) interview, thence (3) focus group discussion.

\section{A. Classroom Observation}

The researcher conducts online classroom observation twice to each participant's class by joining the online class throughout the Zoom meeting. The classroom observation checklists are used to describe the strategies applied by the teachers in detail. After the data are obtained, they are classified into six aspects that are; conversation, partner work, talking partner, role-play, the use of media, and the effectiveness of strategies.

\section{B. Interview}

An interview is conducted to each of the respondents. Semi structured interview is chosen in order to find out in depth information related to the strategies applied in teaching spoken language to young learners. The interviewer provides 11 questions to answer that are also followed up with some additional questions. Each participant is interviewed throughout the Zoom meeting to answer the interview's questions. The interview is conducted online by using the video conference in the Zoom application. Therefore, the answers from the respondents form in the transcription of the Zoom recording.Cara mudah untuk menyesuaikan artikel sesuai dengan ketentuan di Pedagonal : Jurnal Ilmiah Pendidikan atan template adalah dengan menggunakan dokumen ini sebagai template dan cukup ketik langsung teks penulis ke dalamnya.

\section{Focus Group Discussion}

Focus group discussion (FGD) is done online throughout the Zoom meeting. The questions discussed in the focus group discussion contain of probe questions and follow up questions. Focus Group Discussion is chosen as one of the third non- test instrument since throughout the discussion of FGD, the information gathered is more focused and it enables the researcher to understand the diversity between each participant point of view towards the topic. Moreover, the number of participants in this research meets the minimum criteria to conduct a focus group discussion. As suggested by Koentjoro (2005) that the number of participants of focus group discussion is obviously arranged in the small group of 4-7 participants

\section{DATA DESCRIPTION}

\section{A. Data of Classroom Observation}

The data of classroom observation was obtained through the online observation using the Zoom application. The observation was done twice for each participant's on Monday, 15th February and on the next Monday, 22nd of February 2021. The data that was collected using the classroom observation checklists that contain the description of strategies done by the participants that was focused on activities in teaching spoken language. Conforming to what is mentioned earlier in the previous chapter, there are four activities that can be brought in the class as the ways to teach spoken language to young learners such as practicing conversation, talking partner, partner work, and role-play in the class.

Based on the data, it shows that the majority of the respondents employ conversation as one of the ways in teaching spoken language to young learners. Furthermore, the finding shows that most of the respondents also employ repetition as another way to teach the students spoken language. In addition, from the data of observation, it is found that the majority of the respondents use pictures and flashcards as the medium to assist the students in learning spoken language.

\section{B. Data of Interview}

The interview was conducted on 24th and 26th of February 2021. It was done online throughout the video conference of Zoom meeting. There were eleven questions and some follow up questions asked to each respondent. The semi structured interview was chosen in order to gain in depth data from each respondent's point of view related to the topic. 
The first question of interview talks about how the teachers assist the students in being used to speak English. It is confirmed that the majority of the respondents reveal that they keep using English to the students. Moreover, there is one respondent who adds that she also uses song as other way to help the students use to speak English. From the first question, it is followed up that three respondents state that they use L1 to help the students understand unfamiliar English words. In other words, they translate it first to Bahasa Indonesia. In addition, two respondents say that they use gesture or movement as another way to help them teach the students spoken language.

The second question of interview talks about how the teachers give the students an opportunity to talk. All respondents utter the same answer. They say that they ask question in English to the students so that the students have their turn to answer it in English.

In the third question, each respondent was asked about how each of them trains the students to talk. Three respondents state that they practice daily conversation with the students. Besides, one respondent says that she adds song as the way in training the students to talk

Meanwhile, from the fourth question; it reveals that half of the respondents utter that they bring an interesting topic into a conversation as the way to enhance the students' ability to talk. One respondent says that she brings video and song to enhance the students to talk. While, another one says that she uses story book.

The fifth question of interview talks about the way teachers let students talk with the other students. The majority of the respondents reveal that they provide a show and tell activity. In this activity, the students are given time to talk with their friends throughout the day.

The sixth question of interview talks about the way the teachers improve the collaborative skill of students to work with a partner. Three out of four respondents utter that they coordinate with parents at home to build the partner work during online learning. Meanwhile, a respondent acknowledges that partner work during online learning has not been done effectively.

The seventh question talks about the way the teachers optimize student talk time and student creativity. Half of the respondents utter that they use drawing journal to facilitate the students. On the other side, the rest of the respondents' state that they use open-ended activity.

From the eighth question, it reveals that the teachers create activities that also assist the students in developing the student talk time. Most of the respondents reveal that they use an interesting topic to bring a creation that can also develop the students to talk. Two out of four respondents utter that they use picture. In addition, one of the respondents states that she also adds song. Meanwhile, two other respondents say that they bring the students' cheerfulness they did at home as the topic to create a conversation

Further revealed from the ninth question that the majority of the respondents state the same answer that mostly the medium used are; picture, song, video, and things around to teach the students to speak English.
In the last two questions of interview, each of the respondent was asked to evaluate the effectiveness of teaching strategies applied to teach the students spoken language. Most of the respondents evaluate that those of strategies are effective. The respondents reveal that they help the students to make progress in the learning spoken language. All respondents confess that most of the students have given a good response

\section{Data of Focus Group Discussion}

The discussion was done online on 11th of March 2021 throughout the Zoom meeting. A total of eight questions were discussed with all the respondent. The questions asked in the discussion contain of two probe questions and six follow up questions.

The first question of the probe question discusses about the respondents' opinion towards planning a teaching strategy. In the first probe question, the majority of the respondents reveal that the lack of understanding of the students towards English language becomes the number one difficulty when teaching spoken language to young learners. In the second probe question; it talks about the respondents' opinion towards planning a teaching strategy all respondents agree that teachers should plan a teaching strategy. Moreover, it is also revealed from the statement that the lesson plan for each child contains of different teaching strategy.

The follow up question started by discussing how the teachers train the students to talk more and fluently in English. The majority of the respondents reveal that they practice daily conversation with the students in order to train the students to talk more and fluently.

Further question discussed how the teachers train the students' collaborative skill in working with a partner. Most of the respondents say that they train the students' collaborative skill through group time activity. However, a respondent reveals that the partner work has not effectively run well.

In the third question; the discussion talks about how the teachers let the students talk with a partner. All respondents utter that they provide a group time activity in which enables the students to have opportunity to talk with their friends.

Meanwhile, the fourth question discusses how the teachers develop the students' creativity and imagination along with how they develop the student to speak English. A respondent utters that she has played similar activity as role play that was pretend play. However, two respondents state that they have never had role play activity during this online learning.

The fifth question discusses what medium the teachers use to assist the students in learning the spoken language. Two respondents say that they use video, song, worksheet, flashcard, and picture. Meanwhile, another one respondent states that she uses sandpaper letter.

At last, the sixth question discusses what is the most effective strategy used in teaching spoken language to young learners. Most of the respondents argue that video and song 
are the most effective to assist the students in learning spoken language.

\section{DATA ANALYSIS}

\section{A. Conversation}

Teaching children spoken language means ensuring the children with the target language; in this case the target language is English Language. Therefore, in order to assist the children in speaking English, teachers may provide activities that involve the children in a conversation. According to Eggins (2004: 92-93), spoken language is kind of an interactive communication that needs at least two or more participants. The communication should be face to face and spontaneous. In this case, it should be done at the same time and at the same place and it also requires natural responses from the interlocutor without him or her rehearsing what is going to be said. Furthermore, the language used to communicate should be daily use language or informal language.

As also mentioned by Imaniah and Nargis (2017:6364) who state that to teach the students spoken language is to inform them using English language through conversation that can be formed informally and structured. It can be inferred that the teachers have to involve the students in a controlled conversation in order to increase the student talk time.

From the results of triangulation, it shows that the majority of the respondents have done two-way communication with the students throughout both informal and structured conversation. Further revealed that the interaction between the teachers and the students is done throughout the video conference in the Zoom application.

Based on the data of analysis, the respondents acknowledge that practicing daily conversation effectively enhances the student talk time. Moreover, most of the respondents are also found that they use $\mathrm{L} 1$ as the resource to assist the students in learning spoken language. They reveal that there are times when the students are not able to understand some English words. Hence, to overcome the problem, they translate it to L1 or Bahasa Indonesia. The findings match the statement mentioned by Imaniah and Nargis (2017:50) that teachers are suggested to use L1 as the resource as necessary to save time for the target language without losing focus on building communicative skills in English.

On the other side, three out of four respondents are found that they use gestures to assist the children with unfamiliar English words. They acknowledge that teachers have to use gesture and movement to help describe unfamiliar English words therefore the children can understand the meaning of it.

Otherwise, the majority of the respondents are found that they use repetition to assist the students in practicing spoken language. They confess that it is important to practice repetition to the students since it can help them talk more and be more fluent in speaking English. The result matches the findings carried out by Pratama and Awaliyah (2015) in their research.

\section{B. Partner Work}

Besides encouraging their communicative skill teachers are also required to work with students either independently or in a group (Harmer, 2007). It is supported by Scott and Ytreberg (1990:15) who suggest that teachers have to group the children whenever it is possible to do so. As mentioned by Imaniah and Nargis (2017:63-64) another way to develop student talk time is by having an interaction throughout the partner work. In this activity, the teachers may provide activities that focus on oral work.

However, based on the data of analysis, the activity involved working with a partner during this online learning is inefficient. The majority of the respondents reveal that during this online learning, it is quite hard to do a partner work since they are still in the long distance's learning. Therefore, the partner work is only done between students and their parents at home. Further revealed that the activity is only for helping the students finish some tasks they are not able and not allowed to do, for instance; cutting a paper. It can be inferred from the findings that the partner work done during online learning has not done effectively; it is limited only for giving the children instruction and asking them to follow the instruction.

\section{Talking Partner}

Conforming to Imaniah and Nargis (2017:63-64) who utter that another way to support children to spend time speaking English is by giving them opportunity to talk with others. As important as practicing daily conversation, talking partners is also essential to practice since it encourages children to talk more and fluently. Therefore, in order to facilitate the children, teachers should provide the turn for children to have their time to talk with other children.

Based on the data analysis, the majority of the respondents have provided the children time to talk with a partner. Further revealed from the data of interview and focus group discussion that the respondents have a show and tell activity that is done twice a week in a group time activity. In this activity, the children are given time to talk with other children throughout the Zoom meeting. They may share anything and tell about their own to their friend and another child may also join if they find it interesting. The finding matches the statement mentioned by Imaniah and Nargis (2017:39) who state that children enjoy telling their own and listening to stories about something real and imaginary. Besides, the idea of providing a show and tell activity is in the same manner with what is stated by Imaniah and Nargis (2017:50).

\section{Role Play}

Another way to practice purposeful communication with children can be done by using role-play (Imaniah and Nargis, 2017:63-64). In this activity, the children are able to start role-play conversation with their friends or teachers by pretending to be someone else as provided in the topic. Otherwise, role play also provides an opportunity for children 
not only to practice English language but also to develop their creativity throughout the role they play. However, the findings show that the majority of the respondents do not practice role-play as one of the ways to help students develop their creativity and communicative skills in English.

Based on the data analysis, most of the respondents did not look forward to have a role-play activity in the class. Further revealed from the focus group discussion that only the minority of the respondents has ever employed a role play activity during the online learning. Meanwhile, half of the respondents reveal that they use drawing journals as an alternative way to develop both creativity and student talk time. In this activity, the children are allowed to draw anything they want using their imagination. After that they were asked to present the story behind that. The respondents find it effective to develop students' creativity while also encouraging them to practice their speaking.

Moreover, one out of four respondents states that she utilizes the students' cheerfulness at home as the main topic to be discussed in a conversation. She acknowledges that bringing such a topic is effective to encourage them to practice speaking since they find it interesting to do. The result relates with the statement mentioned by Imaniah and Nargis (2017:42) who state that the ideas and interests that come up from children can drive to an exploration topic which also enables them to spend more time speaking English.

Meanwhile, the other respondent reveals that she uses an open-ended activity as another alternative way to develop students' creativity and students' speaking skill. Through the open-ended activity, children are allowed to create something they wish like what they may do in art and craft such as ice cream's college. The children are able to decorate their own ice cream by spreading ice cream topping they want. Further revealed that she finds it effective to encourage the students to develop the students' creativity and also to practice their speaking.

\section{E. The Use of Media}

Young learners' teachers are required to use lots of media to attract the children to speak. Mediums are also suggested to be used when teaching to young learners since it is found exciting for children (Scott and Yteberg, 1990:108). Based on the data analysis, the majority of the respondents have brought medium into the online class. It is found that all respondents use pictures as one of mediums to help the teachers teach the target language to the children. This finding matches the result carried out by Yusuf, et al (2019) in their research.

Further found from the classroom observation and the focus group discussion that the majority of the respondents also use flashcard as the other media. In addition, from the data of interview and focus group discussion; two among four respondents state that they also use song and video as another teaching medium. The results also match the findings carried out by Yusuf, et al (2019) and Pratama and Awaliyah (2015) in their research.

\section{F. The Effectiveness of Strategy}

From the data analysis, the majority of the respondents perceive the strategies employed to teach spoken language to young learners, which are; conversation, talking partner, gesture, repetition, translating the word, picture, and song are effective in assisting children to talk more and fluently. Further revealed that the students show better progress. Moreover, the result from the focus group discussion indicates that song being the most effective media for helping the students to speak.

\section{CONCLUSION}

Based on the data of three steps of triangulation; classroom observation, interview, and focus group discussion, it shows that the teachers' strategies in teaching spoken language to young learners at Cita Harmoni Montessori School are mostly applied in the same ways as suggested by Imaniah and Nargis. The findings show that the teachers employ daily conversation in teaching spoken language to young learners. It is also found that most of the teachers employ repetition in teaching spoken language to the students. Further revealed that daily conversation that is repeatedly practiced enables the students to develop the students' ability to talk since they are driven to keep using English. Besides, the researcher finds that the teachers also employ gestures as one of strategies to assist the student in learning the target language.

Moreover, the teachers also employ a show and tell activity in order to give the students an opportunity to talk with a partner. It is revealed that it can develop the communicative skill of the students to talk with a partner. In addition, it is found that the majority of the teachers use pictures, flashcards, songs, and videos as the mediums to assist the students in learning spoken language.

However, based on the data obtained from triangulation, a partner work activity does not run smoothly during this online learning. Besides, it also happens when employing role play activity. Only the minority of the teachers who has ever employed role play activity during the online learning. It is revealed from the findings of interview and focus group discussion that during this online learning, the activities in the class are mostly reduced due to the limited space and time. Therefore, the teachers find it hard to apply those two strategies above.

It can be concluded that the teachers employ these following as the strategies to teach the students spoken language: conversation, talking partner, picture, flashcard, song, video, gesture, and repetition. From the data gathered through the three steps of triangulation, it is quite clear to see that the strategies applied by the teachers are effective to help the students to talk more and fluently.

In line with the conclusion, there are some suggestions given from the researcher to the teachers. The researcher finds that some students are easily bored when learning language online. Therefore, it is suggested to young learner teachers to create more innovative activities that can also enhance the students to speak English.

The teachers may bring plenty pictures with them since the students find them more interesting. It is also suggested 
for young learner teachers to focus on teaching common words to children since they are inexperienced. However, if they have to learn some new words; it is suggested to limit the number since children need time to recall the words and use them continuously before they can finally understand the meaning of them.

Furthermore, it is advised that the further teacher of young learners to bring an innovative and variative activity that also involves the learner to be more engaged in practicing the spoken English language. Since young learners need to be used to with a new language before they are finally able to learn the language. Some interesting teaching medium that provide chant and colorful picture may also be used in assisting young learners in learning new language.

The suggestion is also advised to the further who has an interest in conducting similar research topics to find out strategies in teaching another aspects or topics to young learners.

\section{REFERENCES}

Adisiti, A.R. (2018). "The Montessori's Values in Teaching English to Young Learners (TEYL)”. Didaktis: Jurnal Pendidikan dan Ilmu Pengetahuan. 18 (2).

Dixit, A.K, and Nalebuff, B.J. (2008). The Art of Strategy. New York: W.W.Norton \&amp; Company.

Eggins, S. (2004): An Introduction to Systematic Functional Linguistics. New York: Continuum International Publishing.

Grey, C.S. (2006): Strategy and History. New York: Routledge

Harmer, J. (2007). The Practice of English Language Teaching. Essex: Pearson Longman.

Imaniah, I, and Nargis. (2017): Teaching English for Young Learners. Tangerang: FKIP UMT Press.

Lestari, A.P. (2011). Teaching English to Very Young Learners. Published Thesis, Sanata Dharma University.

Liyaningsih, G.N.I. (2017). Teachers' Strategies in Teaching English Vocabulary to Young learners. Published Thesis, The State Islamic Institute of Surakarta

Nasution, W.N. (2017): Strategi Pembelajaran. Medan: Perdana Publishing.

Nunan, D. (2011). Teaching English to Young Learners. Anaheim University.

Maulidar, K, Gani, S.A. and Samad, A. (2019). "Teacher's Strategies in Teaching Speaking for Cadets”. English Education Journal. 10 (1).

Pearce, J.A, and Robinson, R.B. (2008). Manajemen Strategik: Formulasi, Implementasi, dan Pengendalian. Jakarta: Salemba Empat.

Philips, S. (1993): Young Learners. Oxford: Oxford University Press.

Pupuh, F, and Sutikno, M.S. (2009). Strategi Belajar Mengajar. Bandung: Refika Aditama.
Pratama, E.Y, and Awaliyah, Y. (2015). Teachers Strategies in Teaching Speaking to Young Learners. English Journal. 9 (2).

Rohrs, H. (2000). "Maria Montessori". UNESCO: International Bureau of Education. XXIV (1/2), 169. 183.

Scott, W.A, and Ytreberg, L.H. (1990). Teaching English to Children. New York: Longman.

Stoner, J.A.F., Freeman, R.E and Gillbert, D.R. (2005). Management (sixth ed.). Pearson.

Sudjana, N. (2014): Dasar-Dasar Proses Belajar Mengajar. Sinar Baru Algesindo.

Wahyuni, N. (2014). Focus Group Discussion. In Bina Nusantara University [Online]. Available: https://qmc.binus.ac.id/2014/08/28/focus-groupdiscussion/ [accessed 18 December 2020]

Widyaningsih, D, and Robiasih, Rr.H. (2018). Teacher's Strategies in Teaching Speaking Skill for Elevanth Grade Students at SMA BOPKRI 2 Yogyakarta. Journal of English Language and Language Teaching. $2(1)$.

Yarger, H.R. (2006): Strategic theory for 21st century: The Little Book on Big Strategy. United States: United States Government.

Yusuf, Y.Q, Burhansyah and Aisyaranur (2019). Teachers' Strategies to Introduce Simple English Word to Very Young Learners. English Education International Conference. 